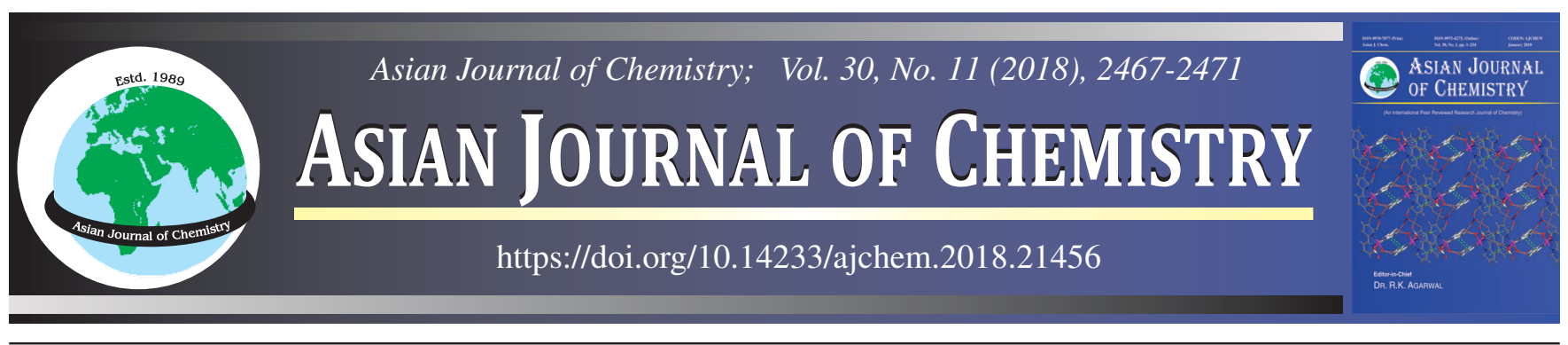

\title{
Studies on Some Mixed Ligand Ternary Complexes of Cerium(III) Employing 1-Nitroso-2-naphthol and Amino Acids
}

\section{G.A. THAKUR ${ }^{1, *}$, U.N. DHAIGUdE ${ }^{1}$ and P.V. BHISE ${ }^{2}$}

${ }^{1}$ Department of Chemistry, Rayat Shikshan Sanstha's, Mahatma Phule Arts, Science and Commerce College, Panvel-410 206, India

${ }^{2}$ Department of Chemistry, Yashwantrao Chavan Institute of Science, Satara-415 001, India

*Corresponding author: Tel/Fax: +91 22 27452561; E-mail: ganeshthakur68@yahoo.co.in

Received: 18 May 2018;

Accepted: 19 July 2018;

Published online: 27 September 2018;

AJC-19096

The mixed ligand ternary complexes of cerium(III) with general formula $\left[\mathrm{Ce}(1 \mathrm{~N} 2 \mathrm{~N})_{2} \cdot(\mathrm{L}) \cdot 2 \mathrm{H}_{2} \mathrm{O}\right]$ where $(1 \mathrm{~N} 2 \mathrm{~N})=1$-nitroso-2-naphthol primary ligand and $\mathrm{L}=$ different amino acids (L-valine, L-serine and L-isoleucine ) as a secondary ligands have been prepared and characterized by IR, UV-visible spectroscopic technique, TG-DTA studies, elemental analysis, magnetic and molar conductance studies

The magnetic susceptibility study indicates paramagnetic nature of the complexes. The electrical conductance values of all the complexes shows their non-electrolytic nature. The metal-ligand bonding through nitrogen and oxygen atom was confirmed by FT-IR spectral studies. The antimicrobial activities of the compounds have been tested against $S$. aureus, C. diphtheria, E. coli and $S$. typhi. These complexes show better antibacterial activity than free ligand.

Keywords: Ternary complexes, Cerium, 1-Nitroso-2-naphthol, Amino acids, Antibacterial activity.

ᄂ - - - - - - - - - - - - - - - - - - - - - - - -

\section{INTRODUCTION}

The literature survey revealed that mixed ligand complexes of some transition metals with amino acids have been studied for their synthesis, spectral and biological importance [1], like antibacterial [2-4], antimicrobial [5,6], antituberculosis assay [7] and as a potential therapeutic agents [8]. The mixed ligand complexes of 1-nitroso-2-naphthol with transition and inner transitiom metals have been reported [9-11]. Similarly, metal complexes of 1-nitroso-2-naphthol and amino acids have been studied for their antibacterial activity $[12,13]$. The lanthanide inner transition cerium(IV) compounds plays the great important role in water gas-shift reaction [14-16] as well as a catalyst [17-19]. Recently, it has been found that the metal complexes of cerium(III) also possess antibacterial activity [20-22].

Thus, it was considered to study the complexation and to determine the biological activity of new cerium(III) complexes. The present paper includes synthesis and characterization of new mixed ligand ternary complexes of cerium(III), employing 1-nitroso-2-naphthol as a primary ligand and different amino acids such as L-valine, $\mathrm{L}$-serine and L-isoleucine as a secondary ligand and were screened for their antibacterial properties.

\section{EXPERIMENTAL}

The AR grade cerium(III) chloride heptahydrate and ligands like 1-nitroso-2-naphthol and different amino acids such as L-valine, L-serine and L-isoleucine was used as such as obtained from S.D.Fine Chemicals, Mumbai. The solvents used ethyl alcohol, N,N-dimethyl formamide and dimethyl sulphoxide were purified by standard procedure [23].

The metal content of the synthesized mixed ligand ternary complexes of cerium(III) was estimated gravimetrically by standard procedure [24]. The electronic absorption spectra of all complexes were recorded in DMF solution $(0.001 \mathrm{M})$ on Shimadzu UV/VIS-1800 spectrophotometer. The Thermo Finnigan Elemental Analyzer was used for $\mathrm{C}, \mathrm{H}$ and $\mathrm{N}$ elemental analysis. The conductance measurement study was carried out in DMF (0.001 M) on an Equiptronics Digital Conductivity Meter. Infrared spectra of all metal complexes as well as ligands were recorded on $\mathrm{KBr}$ disc on using Shimadzu FT-IR spectrophotometer in the region $4000-400 \mathrm{~cm}^{-1}$. In the controlled nitrogen atmosphere the thermal analysis of the complexes was carried on a Perkin-Elmer Diamond TG-DTA instrument at SAIF, IIT Bombay. Magnetic susceptibility measurements

This is an open access journal, and articles are distributed under the terms of the Creative Commons Attribution-NonCommercial 4.0 International (CC BY-NC 4.0) License, which allows others to copy and redistribute the material in any medium or format, remix, transform, and build upon the material, as long as appropriate credit is given and the new creations are licensed under the identical terms. 
for all the complexes were reported at room temperature by the Gouy's method using calibrant as a mercury tetrathiocyanatocobaltate (II).

Preparation of mixed ligand complexes: The mixed ligand ternary complexes of cerium(III) were prepared from $\mathrm{CeCl}_{3} \cdot 7 \mathrm{H}_{2} \mathrm{O}$, 1-nitroso-2-naphthol (1N2N) primary ligand and various amino acids (L-valine, $\mathrm{L}$-serine and $\mathrm{L}$-isoleucine) as a secondary ligands. $10 \mathrm{~mL}$ of $0.001 \mathrm{M}$ aqueous solution of $\mathrm{CeCl}_{3} \cdot 7 \mathrm{H}_{2} \mathrm{O}(0.372 \mathrm{~g}, 1 \mathrm{mmol})$ was prepared and warmed. To this warm solution, $20 \mathrm{~mL}$ of $0.002 \mathrm{M}$ ethanolic solution of 1-nitroso-2-naphthol ( $0.346 \mathrm{~g}, 2 \mathrm{mmol}$ ) was added with constant stirring on magnetic stirrer and $10 \mathrm{~min}$ heated in boiling water bath. To this hot solution, $10 \mathrm{~mL}$ of $0.001 \mathrm{M}$ aqueous solution of corresponding amino acid was added and warmed at $50{ }^{\circ} \mathrm{C}$ in water bath. The complete precipitation of the complexes was carried out by raising the $\mathrm{pH}$ of solution up to 7.0 by adding dilute ammonia solution. The solution was cooled at room temperature and the isolated solid product was filtered, washed with water two to three times and finally with ethanol and dried under vacuum.

\section{Antibacterial screening}

Agar cup method: The antibacterial activity of the synthesized mixed ligand ternary complexes of cerium(III) was tested by using an agar cup method [25] against two Gram-positive and two Gram-negative bacteria namely $S$. aureus, $C$. diphtheria, E. coli and S. Typhi, respectively.

In this method, the sterile nutrient agar along with the desired bacterial strain was allowed to solidify in a sterile plate up to $5 \mathrm{~mm}$ height. Thereafter, by using sterilized cork borer, single cup with diameter $8 \mathrm{~mm}$ was made by scooping out agar medium from the middle portion of the plate and was filled with test solution of $0.001 \mathrm{~g} / \mathrm{mL}$ concentration. The plate was kept in refrigerator for 10 min to diffuse the test solution in surrounding agar and plate was incubated for $24 \mathrm{~h}$ at $37^{\circ} \mathrm{C}$.

The zone of inhibition was measured from the edge of the cup and reported as antibacterial activity of complexes. The results were compared with tetracycline standard, which was screened simultaneously.

Tube dilution method: In the present investigation the synthesized mixed ligand ternary complexes of cerium(III) has been subjected to antibacterial screening skills conducted in vitro study so as to determine their activity against different microorganisms such as Staphylococcus aureus, Corynebacterium diphtheria, Escherichia coli and Salmonella typhi by the serial tube dilution system. The stock solution of cerium complexes in $1 \mathrm{ppm}$ was prepared by using dimethyl sulphoxide. The bacterial inoculums were prepared in Sterilized Muller Hinton broth and incubated for $4 \mathrm{~h}$ at $37{ }^{\circ} \mathrm{C}$. From these bacterial inoculums $5 \mathrm{~mL}$ were spread into a borosilicate test tube. The test sample solution was added in order to attain a final concentration as 5 to $1000 \mu \mathrm{g} / \mathrm{mL}$. Again, $0.1 \mathrm{~mL}$ of inoculums of desired bacteria was added in the tubes. The tubes were kept on a rotary shaker for $24 \mathrm{~h}$ for incubation. On next day results were observed for the presence or absence of growth to estimate minimum inhibition concentration (MIC). The result of synthesized cerium complexes was compared with the antibacterial activity of standard tetracycline which was used as a control.

\section{RESULTS AND DISCUSSION}

The synthesis reaction of mixed ligand ternary complexes of cerium(III) can be represented as follows:

$$
\begin{gathered}
\mathrm{CeCl}_{3} \cdot 7 \mathrm{H}_{2} \mathrm{O}+2(1 \mathrm{~N} 2 \mathrm{~N})+\mathrm{HL} \longrightarrow \\
{\left[\mathrm{Ce}(1 \mathrm{~N} 2 \mathrm{~N})_{2} \cdot(\mathrm{L}) \cdot 2 \mathrm{H}_{2} \mathrm{O}\right]+3 \mathrm{HCl}+5 \mathrm{H}_{2} \mathrm{O}}
\end{gathered}
$$

where, $(1 \mathrm{~N} 2 \mathrm{~N})$ denotes 1-nitroso-2-naphthol and HL represent amino acid.

All the complexes are brown in colour, partly soluble in common organic polar aprotic solvents like dimethyl sulphoxide and $\mathrm{N}, \mathrm{N}$-dimethyl formamide and are insoluble in solvents like acetone, ethyl alcohol, benzene, toluene, methanol etc. These complexes were non-volatile, non-hygroscopic and thermally stable amorphous solids (Table-1). The complexes exhibit strong metal-ligand bond.

The cerium complexes were analyzed for carbon, hydrogen and nitrogen content and the estimated data (Table-2) of metal complexes are in accordance with their 1:2:1 stoichiometric ratios of the type $\left[\mathrm{Ce}(1 \mathrm{~N} 2 \mathrm{~N})_{2} \cdot(\mathrm{L}) \cdot 2 \mathrm{H}_{2} \mathrm{O}\right]$.

The $0.001 \mathrm{M}$ solution of cerium complexes was prepared in $\mathrm{N}, \mathrm{N}$-dimethylformamide and molar conductance values were measured by using Equiptronics Autoranging Conductivity Meter. The recorded electrical conductance data (Table-

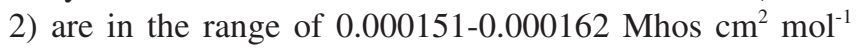
which indicates nonelecrolytic nature of complexes [21].

TABLE-1

EMPIRICAL FORMULA, MOLECULAR WEIGHT, COLOUR, DECOMPOSITION TEMPERATURE AND pH of CERIUM(III) COMPLEXES

\begin{tabular}{cccccc}
\hline Complex & m.f. & m.w. $(\mathrm{g})$ & Colour & Decomposition temp. $\left({ }^{\circ} \mathrm{C}\right)$ & $\mathrm{pH}$ \\
\hline$\left[\mathrm{Ce}(1 \mathrm{~N} 2 \mathrm{~N})_{2}(\mathrm{Val}) \cdot 2 \mathrm{H}_{2} \mathrm{O}\right]$ & $\mathrm{C}_{25} \mathrm{H}_{26} \mathrm{~N}_{3} \mathrm{O}_{8} \mathrm{Ce}$ & 636.60 & Brown & 200 & 7.10 \\
{$\left[\mathrm{Ce}(1 \mathrm{~N} 2 \mathrm{~N})_{2}(\mathrm{Ser}) \cdot 2 \mathrm{H}_{2} \mathrm{O}\right]$} & $\mathrm{C}_{23} \mathrm{H}_{22} \mathrm{~N}_{3} \mathrm{O}_{9} \mathrm{Ce}$ & 624.55 & Brown & 205 & 6.98 \\
{$\left[\mathrm{Ce}(1 \mathrm{~N} 2 \mathrm{~N})_{2}(\mathrm{Iso}) \cdot 2 \mathrm{H}_{2} \mathrm{O}\right]$} & $\mathrm{C}_{26} \mathrm{H}_{28} \mathrm{~N}_{3} \mathrm{O}_{8} \mathrm{Ce}$ & 650.63 & Brown & 200 & 7.05 \\
\hline
\end{tabular}

$1 \mathrm{~N} 2 \mathrm{~N}$ represents deprotonated 1-nitroso-2-naphthol primary ligand, where as Val, Ser, Iso represents secondary ligands valine, serine and isoleucine, respectively.

TABLE-2

MOLAR CONDUCTANCE AND ELEMENTAL ANALYSIS DATA OF CERIUM(III) COMPLEXES

\begin{tabular}{lccccc}
\hline \multirow{2}{*}{ Complex } & $\begin{array}{c}\text { Molar conductance } \\
\left.\text { (Mhos cm } \text { mol }^{-1}\right)\end{array}$ & \multicolumn{4}{c}{ Elemental analysis (\%): Found (calcd.) } \\
\cline { 3 - 6 } & 0.000162 & $47.13(47.17)$ & $4.09(4.12)$ & $\mathrm{N}$ & $\mathrm{M}$ \\
\hline$\left[\mathrm{Ce}(1 \mathrm{~N} 2 \mathrm{~N})_{2}(\mathrm{Val}) \cdot 2 \mathrm{H}_{2} \mathrm{O}\right]$ & 0.000151 & $44.22(44.23)$ & $3.54(6.60)$ & $22.01(22.00)$ \\
{$\left[\mathrm{Ce}(1 \mathrm{~N} 2 \mathrm{~N})_{2}(\mathrm{Ser}) \cdot 2 \mathrm{H}_{2} \mathrm{O}\right]$} & 0.000162 & $48.01(48.00)$ & $4.34(4.34)$ & $6.71(6.73)$ & $22.40(22.44)$ \\
{$\left[\mathrm{Ce}(1 \mathrm{~N} 2 \mathrm{~N})_{2}(\mathrm{Iso}) \cdot 2 \mathrm{H}_{2} \mathrm{O}\right]$} & & & $6.43(6.46)$ & $21.51(21.54)$ \\
\hline
\end{tabular}


Magnetic study: The calculated magnetic moment values (Table-3) of synthesized mixed ligand ternary complexes of cerium(III) by using magnetic susceptibilities measurements employing diamagnetic corrections were observed in the range of 1.712-1.771 B.M. which indicates their paramagnetic nature [22].

\begin{tabular}{cccc} 
TABLE-3 \\
MAGNETIC SUSCEPTIBILITY DATA OF \\
CERIUM(III) COMPLEXES & $\left(10^{-6}\right.$ c.g.s. UNITS $)$ \\
\hline Complex & $\chi_{\mathrm{g}}$ & $\chi_{\mathrm{m}}$ & $\mu_{\mathrm{eff}}$ (B.M.) \\
\hline$\left[\mathrm{Ce}(1 \mathrm{~N} 2 \mathrm{~N})_{2}(\mathrm{Val}) \cdot 2 \mathrm{H}_{2} \mathrm{O}\right]$ & 1.6148 & 1027.9820 & 1.712 \\
{$\left[\mathrm{Ce}(1 \mathrm{~N} 2 \mathrm{~N})_{2}(\mathrm{Ser}) \cdot 2 \mathrm{H}_{2} \mathrm{O}\right]$} & 1.7660 & 1102.9553 & 1.749 \\
{$\left[\mathrm{Ce}(1 \mathrm{~N} 2 \mathrm{~N})_{2}(\mathrm{Iso}) \cdot 2 \mathrm{H}_{2} \mathrm{O}\right]$} & 1.6960 & 1103.4700 & 1.771 \\
\hline
\end{tabular}

Electronic absorption spectra: The electronic spectra of $0.001 \mathrm{M}$ solution of synthesized mixed ligand ternary complexes of cerium(III) in DMF were carried out in UVvisible region. The UV-visible spectrum of all cerium complexes show three transitions (Table-4). The high intensity band in the range $263-266 \mathrm{~nm}\left(38023-37594 \mathrm{~cm}^{-1}\right)$ assigned to $\pi \rightarrow \pi^{*}$ transitions due to conjugated $\pi$ system. The low intensity second band was observed at wavelength range $328-334 \mathrm{~nm}$ $\left(30488-29940 \mathrm{~cm}^{-1}\right)$ attributed to $\mathrm{n} \rightarrow \pi^{*}$ transition and the third intensity band at wavelength range 393-405 nm (25445-24691 $\mathrm{cm}^{-1}$ ) ascribed to L-M charge transfer transitions.

\section{TABLE-4}

ELECTRONIC SPECTRAL DATA OF CERIUM(III) COMPLEXES

\begin{tabular}{cccc}
\hline \multicolumn{1}{c}{ Complex } & $\lambda(\mathrm{nm})$ & $v\left(\mathrm{~cm}^{-1}\right)$ & $\begin{array}{c}\text { Proposed } \\
\text { assignments }\end{array}$ \\
\hline$\left[\mathrm{Ce}(1 \mathrm{~N} 2 \mathrm{~N})_{2}(\mathrm{Val}) \cdot 2 \mathrm{H}_{2} \mathrm{O}\right]$ & 263 & 38023 & $\pi \rightarrow \pi^{*}$ \\
& 329 & 30395 & $\mathrm{n} \rightarrow \pi^{*}$ \\
& 396 & 25253 & Charge-transfer \\
\hline$\left[\mathrm{Ce}(1 \mathrm{~N} 2 \mathrm{~N})_{2}(\mathrm{Ser}) \cdot 2 \mathrm{H}_{2} \mathrm{O}\right]$ & 264 & 37879 & $\pi \rightarrow \pi^{*}$ \\
& 334 & 29940 & $\mathrm{n} \rightarrow \pi^{*}$ \\
& 405 & 24691 & Charge-transfer \\
\hline$\left[\mathrm{Ce}(1 \mathrm{~N} 2 \mathrm{~N})_{2}(\mathrm{Iso}) \cdot 2 \mathrm{H}_{2} \mathrm{O}\right]$ & 266 & 37594 & $\pi \rightarrow \pi^{*}$ \\
& 328 & 30488 & $\mathrm{n} \rightarrow \pi^{*}$ \\
& 393 & 25445 & Charge-transfer \\
\hline
\end{tabular}

Infrared spectra: The FT-IR spectrum analysis of the cerium complexes were recorded in potassium bromide disc in range $4000-400 \mathrm{~cm}^{-1}$ and collected data have been summarized in (Table-5).

The broad band around $3435-3431 \mathrm{~cm}^{-1}$ is assigned to asymmetric and symmetric $\mathrm{O}-\mathrm{H}$ stretching vibrations which imply the presence of coordinated water molecule [26] in the synthesized cerium complexes. This was further authenticated by thermal study.
The spectrum of cerium complexes shows two characteristic bands around 1616-1614 and 1400-1398 $\mathrm{cm}^{-1}$ which ascribed to asymmetric and symmetric vibrations of the carboxylate groups $\left(\mathrm{COO}^{-}\right)$of amino acids. However, these asymmetric and symmetric vibration modes of $\left(\mathrm{COO}^{-}\right)$group of free amino acids were observed in the range 1600-1560 and $1415 \mathrm{~cm}^{-1}$. This indicates coordination between carboxylic acid group of amino acid and cerium metal ion via oxygen atom.

The peaks observed in the range $3650-3200 \mathrm{~cm}^{-1}$ in the spectrum of free amino acid due to $\mathrm{O}-\mathrm{H}$ stretching vibrations were found absent in the spectra of cerium complexes. This confirms that $-\mathrm{OH}$ group of carboxylic acid bonded to metal ion through oxygen atom.

Simillarly the band observed in the spectra of cerium complexes in the range of 3132-3115 and $3061 \mathrm{~cm}^{-1}$ for N-H asymmetric and $\mathrm{N}-\mathrm{H}$ symmetric vibrations. However in the free amino acid $\mathrm{N}-\mathrm{H}$ asymmetric and $\mathrm{N}-\mathrm{H}$ symmetric vibration mode was observed at 3040 and $2960 \mathrm{~cm}^{-1}$, respectively.

Also the (C-N) symmetric stretching band observed at $900 \mathrm{~cm}^{-1}$ in the spectra of free amino acids was shifted to lower wave number in the range of $840-839 \mathrm{~cm}^{-1}$ in the spectra of the complexes. This $\mathrm{N}-\mathrm{H}$ vibration shift to higher wave numbers and $\mathrm{C}-\mathrm{N}$ stretching frequency mode to lower wave number indicates the coordination between amino group of amino acid with cerium metal ion through nitrogen atom.

The absorption band observed at $3448 \mathrm{~cm}^{-1}$ can be assigned to free $\mathrm{O}-\mathrm{H}$ group of 1-nitroso-2-naphthol which indicates that $\mathrm{OH}$ group of 1-nitroso-2-naphthol moiety undergoes deprotonation to form complexes. The strong $v(\mathrm{CO})$ band has been reported in the range $1170-1109 \mathrm{~cm}^{-1}$ in silver metal complexes with 1-nitroso-2-naphthol [27]. The strong $v(\mathrm{CO})$ band in synthesized cerium(III) complexes at $1155 \mathrm{~cm}^{-1}$ indicates that the complex contains 1-nitroso-2-naphthol and confirms the bonding between cerium metal and 1-nitroso-2-naphthol ligand via hydroxyl oxygen atom. The metal complexes with 1-nitroso2-naphthol predict the variation in position of $v(\mathrm{CO})$ band.

The observed $v(\mathrm{~N}=\mathrm{O})$ band at $1527 \mathrm{~cm}^{-1}$ of 1-nitroso-2naphthol free ligand was shifted to higher wave number 1554 $\mathrm{cm}^{-1}$ in the spectra of synthesized cerium complexes, which indicates that 1-nitroso-2-naphthol coordinated to metal ion via nitrogen atom.

Further, some new bands were observed over the range of 526-522 and 638-636 cm $\mathrm{cm}^{-1}$ with weak intensity which corresponds to $\mathrm{M}-\mathrm{N}$ and $\mathrm{M}-\mathrm{O}$ stretching vibrations, respectively, which were absent in both free ligand, 1-nitroso-2-naphthol and amino acids.

Thermal studies: The thermal study of mixed ligand ternary complexes of cerium(III) was recorded in an inert nitrogen atmosphere and gradual weight loss due to decomposition

\begin{tabular}{|c|c|c|c|c|c|c|c|c|c|c|c|}
\hline \multicolumn{12}{|c|}{$\begin{array}{c}\text { TABLE-5 } \\
\text { FT-IR SPECTRAL DATA OF CERIUM(III) COMPLEXES }\left(\mathrm{cm}^{-1}\right)\end{array}$} \\
\hline Complex & $\begin{array}{c}v(\mathrm{O}-\mathrm{H}) \\
\mathrm{H}_{2} \mathrm{O}\end{array}$ & $\begin{array}{l}v(\mathrm{~N}-\mathrm{H}) \\
\text { Asym. } \\
\text { (A.a.) }\end{array}$ & $\begin{array}{c}v(\mathrm{~N}-\mathrm{H}) \\
\text { Sym. } \\
\text { (A.a.) }\end{array}$ & $\begin{array}{l}v(\mathrm{C}=\mathrm{O}) \\
\text { (A.a.) }\end{array}$ & $\begin{array}{l}v(\mathrm{C}-\mathrm{O}) \\
\text { (A.a.) }\end{array}$ & $\begin{array}{l}v(\mathrm{C}-\mathrm{N}) \\
\text { (A.a.) }\end{array}$ & $\begin{array}{l}v(\mathrm{~N}=\mathrm{O}) \\
1 \mathrm{~N} 2 \mathrm{~N}\end{array}$ & $\begin{array}{l}v(\mathrm{C}-\mathrm{N}) \\
1 \mathrm{~N} 2 \mathrm{~N}\end{array}$ & $\begin{array}{l}v(\mathrm{C}-\mathrm{O}) \\
1 \mathrm{~N} 2 \mathrm{~N}\end{array}$ & $v(\mathrm{Ce}-\mathrm{O})$ & $v(\mathrm{Ce}-\mathrm{N})$ \\
\hline$\left[\mathrm{Ce}(1 \mathrm{~N} 2 \mathrm{~N})_{2}(\mathrm{Val}) \cdot 2 \mathrm{H}_{2} \mathrm{O}\right]$ & $3431 \mathrm{~b}$ & $3122 \mathrm{w}$ & $3061 \mathrm{w}$ & $1616 \mathrm{~s}$ & $1400 \mathrm{w}$ & $839 \mathrm{~m}$ & $1554 \mathrm{~s}$ & $1213 \mathrm{~m}$ & $1155 \mathrm{w}$ & $636 \mathrm{w}$ & $524 \mathrm{w}$ \\
\hline$\left[\mathrm{Ce}(1 \mathrm{~N} 2 \mathrm{~N})_{2}(\mathrm{Ser}) \cdot 2 \mathrm{H}_{2} \mathrm{O}\right]$ & $3429 \mathrm{~b}$ & $3132 \mathrm{w}$ & $3061 \mathrm{w}$ & $1616 \mathrm{~s}$ & $1400 \mathrm{w}$ & $839 \mathrm{~m}$ & $1554 \mathrm{~s}$ & $1211 \mathrm{~m}$ & $1155 \mathrm{w}$ & $636 \mathrm{w}$ & $522 \mathrm{w}$ \\
\hline$\left[\mathrm{Ce}(1 \mathrm{~N} 2 \mathrm{~N})_{2}(\mathrm{Iso}) \cdot 2 \mathrm{H}_{2} \mathrm{O}\right]$ & $3435 \mathrm{~b}$ & $3115 \mathrm{w}$ & $3061 \mathrm{w}$ & $1614 \mathrm{~s}$ & $1398 \mathrm{w}$ & $840 \mathrm{~m}$ & $1554 \mathrm{~s}$ & $1211 \mathrm{~m}$ & $1155 \mathrm{w}$ & $638 \mathrm{w}$ & $526 \mathrm{w}$ \\
\hline
\end{tabular}

A.a. = Amino acids, $1 \mathrm{~N} 2 \mathrm{~N}=1$-nitroso-2-naphthol 


\begin{tabular}{|c|c|c|c|c|}
\hline \multicolumn{5}{|c|}{$\begin{array}{c}\text { TABLE-6 } \\
\text { THERMAL STUDY DATA OF CERIUM(III) COMPLEXES }\end{array}$} \\
\hline \multirow{2}{*}{ Complex } & \multirow{2}{*}{ Temperature range $\left({ }^{\circ} \mathrm{C}\right)$} & \multirow{2}{*}{ Weight loss due to } & \multicolumn{2}{|c|}{ Loss in weight $(\%)$} \\
\hline & & & Found & Calculated \\
\hline \multirow{3}{*}[\mathrm{Ce}(1\mathrm{N}2\mathrm{N})_{2}(\mathrm{Val})\cdot2\mathrm{H}_{2}\mathrm{O}]{} & $110-152$ & Two water molecules & 5.34 & 5.66 \\
\hline & $200-276$ & Amino acids & 19.32 & 18.24 \\
\hline & $320-533$ & Two $1 \mathrm{~N} 2 \mathrm{~N}$ molecules & 54.01 & 53.77 \\
\hline \multirow{3}{*}[\mathrm{Ce}(1\mathrm{N}2\mathrm{N})_{2}(\mathrm{Ser})\cdot2\mathrm{H}_{2}\mathrm{O}]{} & $120-171$ & Two water molecules & 5.34 & 5.77 \\
\hline & $205-281$ & Amino acids & 17.32 & 16.66 \\
\hline & $343-650$ & Two $1 \mathrm{~N} 2 \mathrm{~N}$ molecules & 55.34 & 54.81 \\
\hline \multirow{3}{*}[\mathrm{Ce}(1\mathrm{N}2\mathrm{N})_{2}(\mathrm{Iso})\cdot2\mathrm{H}_{2}\mathrm{O}]{} & $115-148$ & Two water molecules & 5.34 & 5.54 \\
\hline & $200-267$ & Amino acids & 20.66 & 20.00 \\
\hline & $305-600$ & Two 1N2N molecules & 52.0 & 52.61 \\
\hline
\end{tabular}

of the complex by fragmentation at $10{ }^{\circ} \mathrm{C} / \mathrm{min}$ heating rate was noted (Table-6). The thermogram curves of synthesized cerium complexes show three different decomposition stages. In the first stage, the weight loss observed in the temperature range of $110-171^{\circ} \mathrm{C}$ may be due to the loss of two water molecules. In the second stage, loss in weight in the temperature range $200-281{ }^{\circ} \mathrm{C}$ which may be due to decomposition of an amino acid moiety. In the third stage, weight loss observed in the temperature range $305-650^{\circ} \mathrm{C}$ confirms decomposition of 1-nitroso-2-naphthol from complexes. The heating was carried out until there was no further loss in weight. Above $650{ }^{\circ} \mathrm{C}$ a constant plateau indicates that complexes undergoes complete decomposition and forms the metal oxide as final product which was confirmed by X-ray diffraction study [28].

The DTA (differential thermal analysis) curve of all cerium(III) complexes shows a small endothermic peak in the temperature range $102-170{ }^{\circ} \mathrm{C}$ which indicates the presence of coordinated water molecules. The DTA curve shows small and broad exothermic peak in the range 200-281 and 305$650{ }^{\circ} \mathrm{C}$ due to decomposition of amino acids and 1-nitroso-2naphthol moieties from cerium complexes.

From the physico-chemical studies the proposed structure and bonding of cerium(III) complexes may be represented as shown in Fig. 1.

Antibacterial studies: In the biological evaluation, the antibacterial activity of mixed ligand ternary complexes of cerium(III) was performed using the diffusion agar cup and a tube dilution technique. The cerium complexes indicates a promising biological activity against two Gram-positive and two Gram-negative bacteria namely S. aureus, C. diphtheria, E. coli and S. typhi.
The data of agar cup method listed in Table-7 show that the complexes were more sensitive against $S$. aureus and $S$. typhi in comparison with $C$. diphtheria and $E$. coli. The minimum inhibhitary concentration (MIC) of the cerium complexes, ligands and cerium salts (Table-8) was found in the range of 05-35, 100-150 and 75-150 $\mu \mathrm{g} / \mathrm{mL}$, respectively. Thus complexes are found to be more active against S. typhi and S. aureus as compared to $C$. diphtheria and $E$. coli. Also the complexes show moderate activity as compared to tetracycline standard control.

\begin{tabular}{lcccc} 
TABLE-7 \\
ANTIBACTERIAL ACTIVITY (mm) OF CEIUM(III) \\
COMPLEXES BY AGAR CUP METHOD \\
\hline Complex & $\begin{array}{c}\text { S. } \\
\text { aureus }\end{array}$ & $\begin{array}{c}\text { C. } \\
\text { diphtheriae }\end{array}$ & E. coli & S. typhi \\
\hline$\left[\mathrm{Ce}(1 \mathrm{~N} 2 \mathrm{~N})_{2}(\mathrm{Val}) \cdot 2 \mathrm{H}_{2} \mathrm{O}\right]$ & 26 & 15 & 13 & 21 \\
{$\left[\mathrm{Ce}(1 \mathrm{~N} 2 \mathrm{~N})_{2}(\mathrm{Ser}) \cdot 2 \mathrm{H}_{2} \mathrm{O}\right]$} & 24 & 12 & 14 & 25 \\
{$\left[\mathrm{Ce}(1 \mathrm{~N} 2 \mathrm{~N})_{2}(\mathrm{Iso}) \cdot 2 \mathrm{H}_{2} \mathrm{O}\right]$} & 26 & 15 & 13 & 23 \\
Tetracycline & 32 & 15 & 15 & 26 \\
\hline
\end{tabular}

\begin{tabular}{lcccc}
\multicolumn{5}{c}{ TABLE-8 } \\
MIC $(\mu \mathrm{g} / \mathrm{mL})$ DATA OF CERIUM(III) COMPLEXES \\
\hline \multicolumn{1}{c}{ Complex } & $\begin{array}{c}\text { S. } \\
\text { aureus }\end{array}$ & $\begin{array}{c}\text { C. } \\
\text { diphtheriae }\end{array}$ & E. coli & S. typhi \\
\hline$\left[\mathrm{Ce}(1 \mathrm{~N} 2 \mathrm{~N})_{2}(\mathrm{Val}) \cdot 2 \mathrm{H}_{2} \mathrm{O}\right]$ & 15 & 30 & 25 & 05 \\
{$\left[\mathrm{Ce}(1 \mathrm{~N} 2 \mathrm{~N})_{2}(\mathrm{Ser}) \cdot 2 \mathrm{H}_{2} \mathrm{O}\right]$} & 10 & 30 & 35 & 10 \\
{$\left[\mathrm{Ce}(1 \mathrm{~N} 2 \mathrm{~N})_{2}(\mathrm{Iso}) \cdot 2 \mathrm{H}_{2} \mathrm{O}\right]$} & 10 & 35 & 30 & 05 \\
$1-\mathrm{Nitroso}_{2}-$-naphthol & 75 & 200 & 150 & 100 \\
$\mathrm{CeCl}_{3} \cdot 7 \mathrm{H}_{2} \mathrm{O}$ & 75 & 150 & 100 & 75 \\
Tetracycline & 1.5 & 2.0 & 4.0 & 1.5 \\
\hline & & & &
\end{tabular}

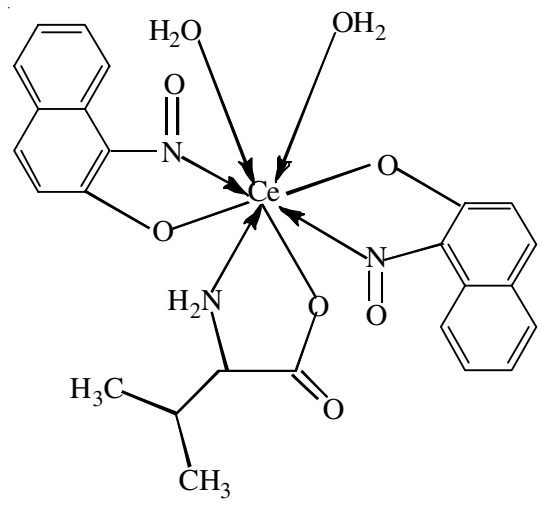

(a)

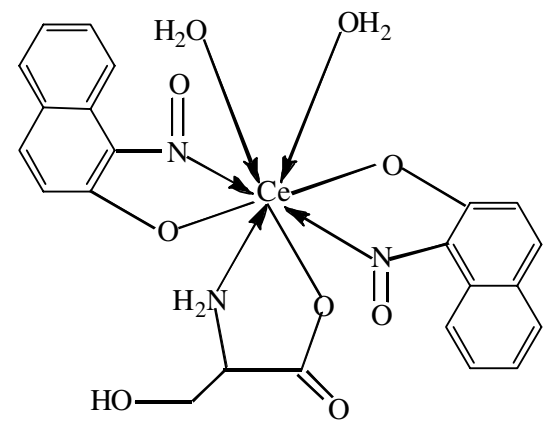

(b)

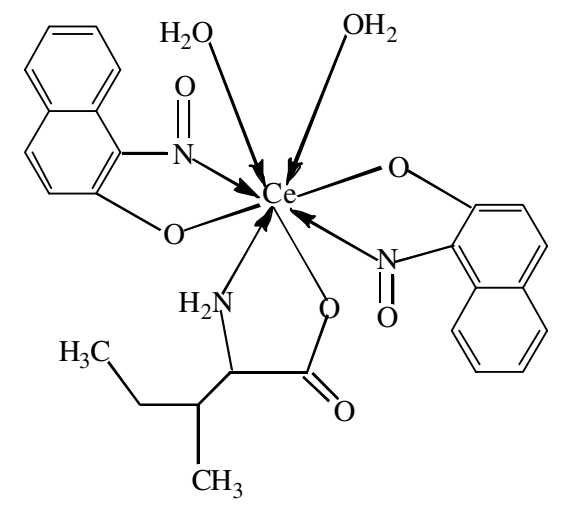

(c)

Fig. 1. Proposed structures of (a) $\left[\mathrm{Ce}(1 \mathrm{~N} 2 \mathrm{~N})_{2}(\mathrm{Val}) \cdot 2 \mathrm{H}_{2} \mathrm{O}\right]$, (b) $\left[\mathrm{Ce}(1 \mathrm{~N} 2 \mathrm{~N})_{2}(\mathrm{Ser}) \cdot 2 \mathrm{H}_{2} \mathrm{O}\right]$, (c) $\left[\mathrm{Ce}(1 \mathrm{~N} 2 \mathrm{~N})_{2}(\mathrm{Iso}) \cdot 2 \mathrm{H}_{2} \mathrm{O}\right]$ 
This indicates that metal complexes exhibit higher antibacterial activity than metal salts and free ligands. The antibacterial activity of metal complexes is enhanced due to chelate effect of ligands which increases the hydrophobic nature that permits the diffusion of the complex through the lipid layer of microorganisms [29].

\section{Conclusion}

The FT-IR spectral analysis of the complexes confirms the metal-ligand bonding through nitrogen and oxygen donor atoms of both ligands. High decomposition temperature in thermal study indicates strong metal-ligand bonding and the presence of a coordinated water molecules in the complexes. The complexes are non-electrolytic and paramagnetic in nature which was confirmed by electrical conductivity and magnetic susceptibility measurement study. All complexes show higher antibacterial activity than free ligands and metal salts. The coordination number of the proposed structure is eight.

\section{ACKNOWLEDGEMENTS}

The authors thanks to Mahatma Phule Arts, Science and Commerce College, Panvel, India for providing laboratory and library facilities.

\section{CONFLICT OF INTEREST}

The authors declare that there is no conflict of interests regarding the publication of this article.

\section{REFERENCES}

1. L.H. Abdel-Rahman, A.M. Abu-Dief, N.M. Ismail and M. Ismael, Inorg. Nano-Met. Chem., 47, 467 (2017); https://doi.org/10.1080/15533174.2015.1137057.

2. M.E. Zayed and R.A. Ammar, Arab. J. Chem., 18, 774 (2014); https://doi.org/10.1016/j.jscs.2011.08.006.

3. G.W. Karpin, J.S. Merola and J.O. Falkinham III, Antimicrob. Agents Chemother., 57, 3434 (2013); https://doi.org/10.1128/AAC.00452-13.

4. S.A. Amolegbe, S. Adewuyi, C.A. Akinremi, J.F. Adediji, A. Lawal, A.O. Atayese and J.A. Obaleye, Arab. J. Chem., 8, 742 (2015); https://doi.org/10.1016/j.arabjc.2014.11.040.

5. W. Beck, Z. Naturforsch., 64b, 1221 (2009).
6. S. Quyoom, Int. J. Chem. Sci., 11, 1448 (2013).

7. K.M. Sultan Al-Juboori, Orient. J. Chem., 33, 2334 (2017); https://doi.org/10.13005/ojc/330524.

8. S. Rafique, M. Idrees, A. Nasim, H. Akbar and A. Athar, Biotechnol. Mol. Biol. Rev., 5, 38 (2010).

9. R.R. Rao and A. Chatt, J. Radioanal. Nucl. Chem., 180, 187 (1994); https://doi.org/10.1007/BF02039918.

10. H. Imam, B. Kumar and M.D. Shafyat, Orient. J. Chem., 27, 287 (2011).

11. F.H. Ghanim, Diyala J. Pure Sci., 8, 118 (2012).

12. N.K. Fayad, T.H. Al-Noor and F.H. Ghanim, Chem. Mater. Res., 2, 18 (2012).

13. T.H. AL-Noor R.M. Hannun and F.H. Ghanim, J. Educ. College (Thi Qar Univ.), 2, 64 (2012).

14. L. Wang and Y. Liu, Chem. Lett., 37, 74 (2008); https://doi.org/10.1246/c1.2008.74.

15. K. Polychronopoulou, C.M. Kalamaras and A.M. Efstathiou, Recent Patents on Mater. Sci., 4, 122 (2011); https://doi.org/10.2174/1874464811104020122.

16. M. Kovacevic, B.L. Mojet, J.G. van Ommen and L. Lefferts, Catal. Lett., 146, 770 (2016); https://doi.org/10.1007/s10562-016-1697-6.

17. C. Walkey, S. Das, S. Seal, J. Erlichman, K. Heckman, L. Ghibelli, E. Traversa, J.F. Mc Ginnis and W.T. Self, Environ. Sci. Nano, 2, 33 (2015); https://doi.org/10.1039/C4EN00138A.

18. A. Davoodnia, M. Khashi and N. Tavakoli-Hoseini, Chin. J. Catal., 35, 1054 (2014); https://doi.org/10.1016/S1872-2067(14)60041-3.

19. S. Kanai, I. Nagahara, Y. Kita, K. Kamata and M. Hara, Chem. Sci., 8, 3146 (2017); https://doi.org/10.1039/C6SC05642C.

20. Z.H.A. El-Wahab, M.M. Mashaly, A.A. Faheim, Chem. Pap., 59, 25 (2005).

21. B.D. Aghav, S.K. Patil and R.S. Lokhande, J. Adv. Appl. Sci. Res., 6, 37 (2015).

22. M. Kekare, V. Vaidya and J. Thakur, Int. J. Sci. Res., 4, 1361 (2015).

23. B.S. Furniss, A.J. Hannaford, P.W.G. Smith and A.R. Tatchell, Vogel's Textbook of Practical organic Chemistry, ELBS, Longmans: London, edn 5 (1989).

24. A.I. Vogel, A Text Book of Quantitative Inorganic Analysis, ELBS, Longman: London, edn 3 (1961).

25. S.S. Patil and M.M. Shaikh, Acta Pol. Pharm. Drug Res., 69, 679 (2012).

26. A.S. Bodkhe, S.S. Patil and M.M. Shaikh, Acta Pol. Pharm. Drug Res., 69, 87 (2012).

27. D. Prakash, B. Kumar, B.G.S. Gupta and B. Kumar, Orient. J. Chem., 25, 809 (2009).

28. G.A. Thakur and S.V. Athlekar, Acta Pol. Pharm. Drug Res., 64, 9 (2007).

29. S. Sanap and R. Patil, Int. J. Pharm. Chem. Sci., 2, 451 (2013). 